\title{
Interactive Effects of PD-LI Expression in Tumor and Immune Cells on Prognosis of Esophageal Squamous Cell Carcinoma: A One-Center Retrospective Cohort Study
}

This article was published in the following Dove Press journal: OncoTargets and Therapy

\begin{abstract}
Feng Shi $\mathbb{I D}^{\prime}$
Shuo Xiao ${ }^{2}$

Kaeli B Miller (D) ${ }^{2}$

Yanjie Zhao (D) $^{3}$

Yuchen $\mathrm{Li} \mathbb{D D}^{4}$

Ying Gao'

Hong Chang'

Qingkun Song ${ }^{5,6}$

Chenxu $\mathrm{Qu}^{7}$

'Department of Pathology, Beijing Shijitan Hospital, Capital Medical University, Beijing 100038, People's Republic of China; ${ }^{2}$ Department of Environmental Health Sciences, Arnold School of Public Health, University of South Carolina, Columbia, SC 29208, USA; ${ }^{3}$ Department of Medical Oncology, Beijing Shijitan Hospital, Capital Medical University, Beijing 100038, People's Republic of China; ${ }^{4}$ Sid Faithfull Brain Cancer Research Laboratory, QIMR Berghofer Medical Research Institute, Brisbane, Queensland, Australia;

${ }^{5}$ Department of Clinical Epidemiology and Evidence-based Medicine, Beijing Shijitan Hospital, Capital Medical University, Beijing 100038, People's Republic of China; ${ }^{6}$ Beijing Key Laboratory of Cancer Therapeutic Vaccines, Beijing Shijitan Hospital, Capital Medical University, Beijing 100038, People's Republic of China; ${ }^{7}$ Gruber Laboratory, University of Southern California, Norris Comprehensive Cancer Center, Los Angeles, CA, USA
\end{abstract}

Correspondence: Qingkun Song Department of Clinical Epidemiology and Evidence-based Medicine, Beijing Shijitan Hospital, Capital Medical University, Tieyi Road I0, Haidian District, Beijing I00038,

People's Republic of China

Tel +86-10-6392690।

Email songqingkun@ccmu.edu.cn
Purpose: The present study aimed to investigate the prognostic effect of PD-L1 expressing in tumor and immune cells among patients with esophageal squamous cell carcinoma.

Patients and Methods: We performed a retrospective cohort study by consecutively recruiting 142 patients. The clinicopathological features and PD-L1 expression on tumor and immune cells were independently evaluated by two pathologists.

Results: The median expression rate of PD-L1 was 5\% and 30\% in tumor and immune cells, respectively. Patients with higher expression of PD-L1 in tumor cells had shorter disease-free and overall survival, and the HRs were 1.52 for relapse $(95 \%$ CI: $0.88,2.60)$ and 1.48 for death $(95 \%$ CI: $0.82,2.69)$. There was no significant association between the PD-L1 expression in immune cells and survival. However, among the patients with PD-L1 expression rate $\leq 30 \%$ in immune cells, the high expression rate of PD-L1 in tumor cells was significantly associated with the relapse and death, with HRs of 2.51 (95\% CI: 1.25, 5.06) and 3.51 (95\% CI: 1.57, 7.85), respectively. Among patients with PD-L1 expression rate $>30 \%$ in immune cells, the PD-L1 expression in tumor cells did not show any association with the disease-free and overall survival. Conclusion: Our study demonstrates that the integration of PD-L1 expression in tumor and immune cells could be used to predict the relapse and survival among patients with esophageal squamous cell carcinoma.

Keywords: esophageal squamous cell carcinoma, PD-L1, prognosis, tumor cells and immune cells, tumor microenvironment

\section{Introduction}

According to the report of GLOBOCAN 2018, the esophageal cancer (EC) ranked the seventh and sixth for incidences and mortality, respectively, in the world. ${ }^{1}$ China has the largest challenge of EC burden, accounting for nearly half of newly diagnosed cases and deaths worldwide. ${ }^{1}$ Esophageal squamous cell carcinoma (ESCC) was the predominant type of EC in China. ${ }^{2}$ With the remarkable improvements in the techniques of diagnosis and treatment, and socioeconomic status, the morbidity and mortality rate of ESCC had decreased over the past several decades, but the prognosis was still unfavorable. ${ }^{3}$ The 5 -year overall survival (OS) rate of advanced ESCC was around $20 \%{ }^{3}$ Thus far, the immunotherapy had achieved very significant efficacy in a variety of tumors and was speculated to become the main treatment method of ESCC. ${ }^{4,5}$ 
Programmed death-ligand 1 (PD-L1) is also known as B7 homologous protein 1 and CD274, and expressed in tumor cells (TC) and immune cells (IC). But the expression in TC and IC has distinct functions in tumor microenvironment. PD-L1 in TC, combining with PD-1 in IC induced tumor occurrence and development by promoting tumor immune escape. ${ }^{6,7}$ PD-L1 in tumor-infiltrating IC, combining with PD-1 induced the inhibition of $\mathrm{T}$ cells activation, apoptosis and immune dysfunction. ${ }^{6,7}$

The relationship between the expression of PD-L1 and the prognosis of EC has been a major research focus but remains controversial. Some studies found that the PD-L1 expression was a favorable predictor in ESCC patients. ${ }^{8,9} \mathrm{In}$ contrast, other studies reported that the PD-L1 expression was associated with the poor prognosis. ${ }^{10-12}$ Since TC and IC had distinctive features of PD-L1, the present study aimed to explore the interactive prognostic effect of PD-L1 expressed in TC and IC on the relapse and survival of ESCC patients.

\section{Patients and Methods}

\section{Patients and Samples}

This retrospective cohort study recruited 142 patients who received neither neoadjuvant therapy nor immunotherapy prior to surgery, from Beijing Shijitan Hospital, Capital Medical University between 2013 and 2016. Based on the cancer location, patients received an Ivor-Lewis esophagectomy or three-incision esophagectomy and were diagnosed as ESCC. There were nine patients occurring perioperative death and excluded from the survival analysis. The tissues were fixed in $4 \%$ neutral formaldehyde and embedded in paraffin for further hematoxylin and eosin (HE) staining and immunohistochemistry (IHC).

\section{Clinical and Pathological Data}

Clinical and pathological data including age, gender, tumor location, tumor size, tumor differentiation, clinical stage, nerve invasion, vascular invasion and lymph node metastasis were collected from medical records. The clinical staging evaluation was conducted according to the 8th edition of AJCC Esophageal Cancer Staging System. The pathological data were independently evaluated by two pathologists. The data of relapse and OS were followed up every 6 months until March 2018.

\section{IHC Procedures}

The two-step method of EnVision was used to detect PD-L1 expression in tumor microenvironment by automatic IHC instrument. Specifically, paraffin-embedded samples were cut into $4 \mu \mathrm{m}$ sections, placed on polylysine-coated slides, deparaffinized with xylene and dehydrated in alcohol series. The slides were washed in 3\% hydrogen peroxide solution at room temperature for 10 minutes, and then in PBS for 5 minutes three times. Slides were repaired in citrate buffer ( $\mathrm{pH} \sim 6.0$ ) by microwave for 20 minutes, cooled to room temperature, and then washed in PBS for 5 minutes three times. Slides were incubated with anti-PD-L1 polyclonal antibody (SP142, diluted with 1:200, Roche Ltd. Shanghai) in a moist chamber at $4^{\circ} \mathrm{C}$ overnight, and then washed in PBS for three times. The secondary antibody was added (Beijing Zhongshanjinqiao biotechnology co., LTD.) and incubated for 20 minutes at room temperature. The slides were washed in PBS for 5 minutes three times. One hundred microliter appropriately diluted Sav-HRP conjugates were added to the sections, incubated in a humidified chamber at room temperature for 30 minutes and washed in PBS for 5 minutes three times. One hundred-microliter DAB substrate solution was added to the sections to reveal the color of antibody staining and the color-desired intensity was reached by color development for $<5 \mathrm{~min}$. The slides were washed in PBS for 5 minutes three times and counterstained with hematoxylin.

\section{Assessment of PD-LI}

Tonsil tissues were used as positive controls for PD-L1 staining. The positive cell had a partial or complete cell membrane staining of brown. The expression rate of PD-L1 was calculated by counting at least 100 cells in three different fields and calculating the mean. The expression rate of PD-L1 in TC and IC were evaluated, respectively. Immunohistochemically stained slides from each subject were reviewed by two pathologists independently and any inconsistent assessments between the two pathologists were consulted by a third pathologist with a higher professional level.

\section{Statistical Analyses}

All analyses were processed by SPSS version 19.0. The expression rate of PD-L1 was measured by median and interquartile range (IQR). Age, cancer location, differentiation and stage were analyzed with PD-L1 expression rate by the Spearman correlation test. Sex, periesophageal lymph node metastasis, perigastric lymph node metastasis, mediastinal peripheral lymph node metastasis, nerve invasion and blood vessel invasion were analyzed with PD-L1 expression by the Wilcoxon rank-sum test. The PD-L1 expression rate was categorized by median. A Kaplan-Meier survival curve was used to estimate the difference of disease-free survival (DFS) 
and OS between high and low expression of PD-L1 with a Log-rank test. A Cox-Hazard Proportion regression model was used to estimate the hazard ratio (HR) and $95 \%$ confidence interval $(95 \% \mathrm{CI})$, with further confounder adjustment. All analyses were two-tailed and the significance level was 0.05 .

\section{Results}

The median expression rate of PD-L1 was $5 \%$ in TC with an IQR of $20 \%$ and $30 \%$ in IC with an IQR of $30 \%$. The median follow-up time was 22 months and the rate of loss for follow-ups was $21.1 \%$.

The PD-L1 expression in TC had a negative correlation with age and the correlation coefficient was -0.17 ( $\mathrm{p}=0.049$, Table 1). The PD-L1 expression in TC had no significant relationship with the sex, cancer location and differentiation (Table 1). The PD-L1 expression in IC had no association with age, sex, cancer location or differentiation (Table 1).

Patients with blood vessel invasion had a PD-L1 expression rate of $20 \%$ in $\mathrm{TC}$, which was significantly higher than the patients without blood vessel invasion $(2 \%, \mathrm{p}=0.008$, Table 2). The expression rate of PD-L1 in TC was not associated with lymph node metastasis, cancer stage or nerve invasion (Table 2). PD-L1 expression in IC did not have associations with lymph node metastasis, cancer stage, nerve invasion or blood vessel invasion (Table 2).

Patients with an expression rate of PD-L1 $>5 \%$ in TC had a median DFS and OS of 11 and 17 months, respectively, significantly shorter than the patients with an expression rate $\leq 5 \%$ (Figure $1 \mathrm{~A}$ and $\mathrm{B}, \mathrm{p}<0.05$ ). And the high expression in TC introduced a $52 \%$ increased risk of relapse $(\mathrm{HR}=1.52,95 \% \mathrm{CI}: 0.88,2.60)$ and a $48 \%$ increased risk of death $(\mathrm{HR}=1.48,95 \% \mathrm{CI}$ : $0.82,2.69$ ) (Table 3 ). The expression rate of PD-L1 in IC did not have any associations with DFS or OS (Figure 1C and D).

Among patients with PD-L1 expression rate $\leq 30 \%$ in IC, the high expression of PD-L1 in TC (>5\%) was associated with a worse DFS ( $p=0.003$, Figure $2 \mathrm{~A}$ ) and a worse OS ( $<<0.001$, Figure $2 \mathrm{~B})$, and the corresponding HRs were 2.51 (95\% CI: 1.25, 5.06) and 3.51 (95\% CI: 1.57, 7.85), respectively (Table 3). Among patients with the PD-L1 expression rate $>30 \%$ in IC, the PD-L1 expression in TC did not alter the median DFS ( $\mathrm{p}=0.757)$ or OS $(\mathrm{p}=0.818)$ significantly (Figure $2 \mathrm{C}$ and $\mathrm{D}$ ), and the HRs were 1.18 (95\% CI: $0.41,3.42)$ and 0.88 (95\% CI: $0.28,2.76)$, respectively (Table 3 ).

\section{Discussion}

In the current study, the prognostic effect of PD-L1 expression in TC was only observed among the ESCC patients with the PD-L1 expression rate in IC less than $30 \%$. However, for patients with PD-L1 expression rate in IC higher than $30 \%$, no significant association was observed. These results indicated that TC and IC expressing PD-L1 had an interactive effect on ESCC

Table I Association Between PD-LI Expression and Basic Characteristics of ESCC

\begin{tabular}{|c|c|c|c|c|c|c|}
\hline & \multicolumn{2}{|c|}{$\begin{array}{l}\text { Expression Rate of PD-LI in Tumor } \\
\text { Cells }\end{array}$} & \multirow[t]{2}{*}{ p-value } & \multicolumn{2}{|c|}{$\begin{array}{l}\text { Expression Rate of PD-LI in Immune } \\
\text { Cells }\end{array}$} & \multirow[t]{2}{*}{ p-value } \\
\hline & Median & IQR & & Median & IQR & \\
\hline Age, correlation coefficient ${ }^{a}$ & -0.166 & - & $0.049^{c}$ & -0.09 & - & 0.297 \\
\hline $\begin{array}{l}\text { Sex }^{b} \\
\quad \text { Male } \\
\text { Female }\end{array}$ & $\begin{array}{l}5 \% \\
1 \%\end{array}$ & $\begin{array}{l}20 \% \\
23 \%\end{array}$ & 0.486 & $\begin{array}{l}30 \% \\
30 \%\end{array}$ & $\begin{array}{l}30 \% \\
31 \%\end{array}$ & 0.595 \\
\hline $\begin{array}{l}\text { Location }^{\mathrm{a}} \\
\text { Upper esophagus } \\
\text { Middle esophagus } \\
\text { Lower esophagus }\end{array}$ & $\begin{array}{l}20 \% \\
5 \% \\
0 \%\end{array}$ & $\begin{array}{l}30 \% \\
20 \% \\
20 \%\end{array}$ & 0.169 & $\begin{array}{l}40 \% \\
20 \% \\
30 \%\end{array}$ & $\begin{array}{l}45 \% \\
30 \% \\
33 \%\end{array}$ & 0.661 \\
\hline $\begin{array}{l}\text { Differentiation }^{\mathrm{a}} \\
\text { Poor } \\
\text { Moderate } \\
\text { Well }\end{array}$ & $\begin{array}{l}2 \% \\
5 \% \\
2 \%\end{array}$ & $\begin{array}{l}48 \% \\
20 \% \\
5 \%\end{array}$ & 0.380 & $\begin{array}{l}20 \% \\
30 \% \\
20 \%\end{array}$ & $\begin{array}{l}20 \% \\
20 \% \\
20 \%\end{array}$ & 0.884 \\
\hline
\end{tabular}

Notes: a Spearman correlation test. ${ }^{b} W$ ilcoxon rank-sum test. ${ }^{c} p<0.05$.

Abbreviations: ESCC, esophageal squamous cell carcinoma; IQR, inter-quartile range. 
Table 2 Relationship Between PD-LI Expression and Pathological Features

\begin{tabular}{|c|c|c|c|c|c|c|}
\hline & \multicolumn{2}{|c|}{$\begin{array}{l}\text { Expression Rate of PD-LI in } \\
\text { Tumor Cells }\end{array}$} & \multirow[t]{2}{*}{ p-value } & \multicolumn{2}{|c|}{$\begin{array}{l}\text { Expression Rate of PD-LI in } \\
\text { Immune Cells }\end{array}$} & \multirow[t]{2}{*}{ p-value } \\
\hline & Median & IQR & & Median & IQR & \\
\hline $\begin{array}{l}\text { Periesophageal lymph node metastasis } \\
\text { No } \\
\text { Yes }\end{array}$ & $\begin{array}{l}2 \% \\
5 \%\end{array}$ & $\begin{array}{l}20 \% \\
20 \%\end{array}$ & 0.788 & $\begin{array}{l}30 \% \\
30 \%\end{array}$ & $\begin{array}{l}30 \% \\
20 \%\end{array}$ & 0.440 \\
\hline $\begin{array}{l}\text { Perigastric lymph node metastasis }{ }^{a} \\
\text { No } \\
\text { Yes }\end{array}$ & $\begin{array}{l}5 \% \\
5 \%\end{array}$ & $\begin{array}{l}20 \% \\
23 \%\end{array}$ & 0.597 & $\begin{array}{l}30 \% \\
20 \%\end{array}$ & $\begin{array}{l}30 \% \\
30 \%\end{array}$ & 0.349 \\
\hline $\begin{array}{l}\text { Mediastinal peripheral lymph node metastasis }{ }^{\mathrm{a}} \\
\text { No } \\
\text { Yes }\end{array}$ & $\begin{array}{l}2 \% \\
20 \%\end{array}$ & $\begin{array}{l}20 \% \\
40 \%\end{array}$ & 0.053 & $\begin{array}{l}30 \% \\
30 \%\end{array}$ & $\begin{array}{l}30 \% \\
20 \%\end{array}$ & 0.908 \\
\hline $\begin{array}{l}\text { Clinical stage }^{\mathrm{b}} \\
\text { I } \\
\text { II } \\
>\text { II }\end{array}$ & $\begin{array}{l}1 \% \\
2 \% \\
5 \%\end{array}$ & $\begin{array}{l}6 \% \\
20 \% \\
30 \%\end{array}$ & 0.184 & $\begin{array}{l}20 \% \\
30 \% \\
25 \%\end{array}$ & $\begin{array}{l}21 \% \\
30 \% \\
20 \%\end{array}$ & 0.827 \\
\hline $\begin{array}{l}\text { Nerve invasion } \\
\text { No } \\
\text { Yes }\end{array}$ & $\begin{array}{l}5 \% \\
5 \%\end{array}$ & $\begin{array}{l}20 \% \\
30 \%\end{array}$ & 0.244 & $\begin{array}{l}30 \% \\
30 \%\end{array}$ & $\begin{array}{l}30 \% \\
20 \%\end{array}$ & 0.857 \\
\hline $\begin{array}{l}\text { Blood vessel invasion }{ }^{\mathrm{a}} \\
\text { No } \\
\text { Yes }\end{array}$ & $\begin{array}{l}2 \% \\
20 \%\end{array}$ & $\begin{array}{l}20 \% \\
35 \%\end{array}$ & $0.008^{c}$ & $\begin{array}{l}20 \% \\
30 \%\end{array}$ & $\begin{array}{l}30 \% \\
20 \%\end{array}$ & 0.157 \\
\hline
\end{tabular}

Notes: ${ }^{2}$ Wilcoxon rank-sum test. ${ }^{b}$ Spearman correlation test. ${ }^{c} p<0.05$.

Abbreviation: IQR, inter-quartile range.

prognosis. Presently, the immune check-point inhibitor, pembrolizumab, has been approved for EC treatment. ${ }^{13}$ The clinical application of pembrolizumab to EC patients is based on the combined positive score of PDL1 expression, which integrated both the expression of PD-L1 on TC and IC. ${ }^{13}$ This study reported the
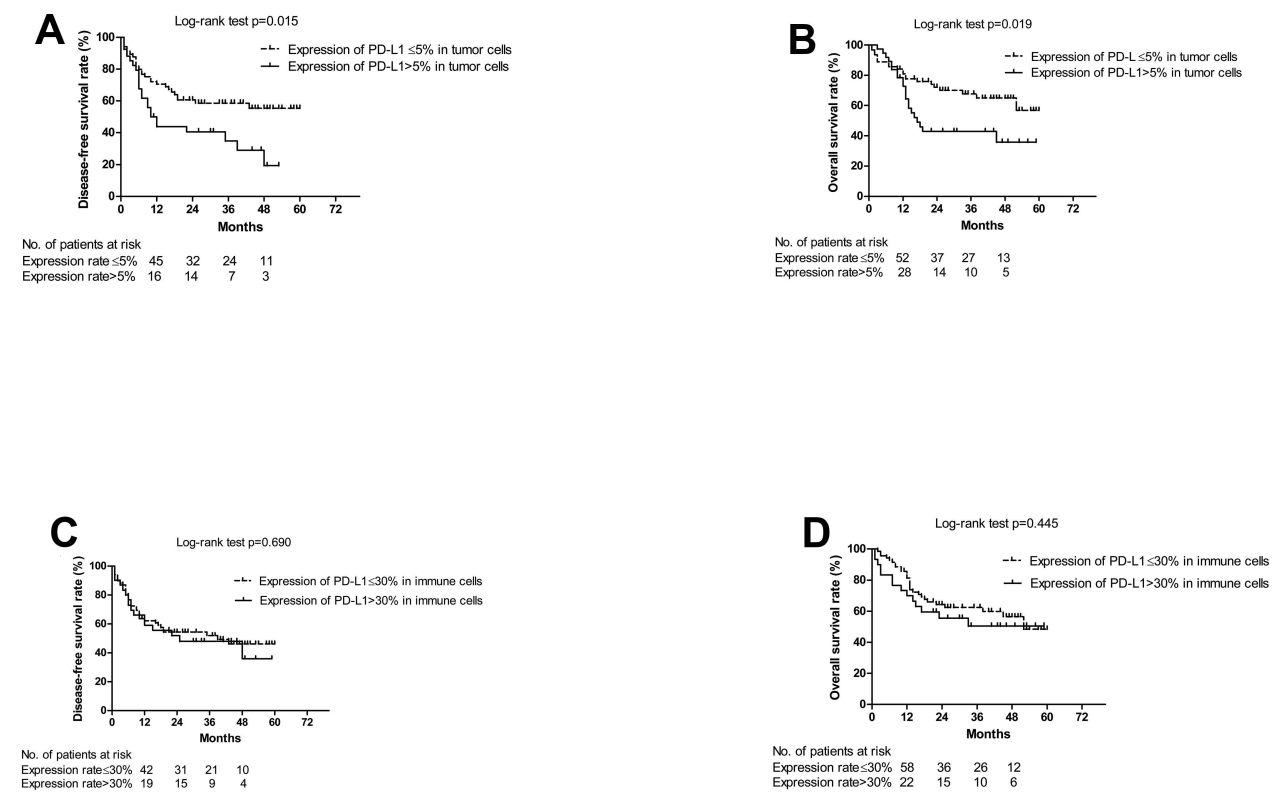

Figure I The association between the survival and PD-LI expression. (A) The association between disease-free survival and PD-LI expression in tumor cells. (B) The association between overall survival and PD-LI expression in tumor cells. (C) The association between disease-free survival and PD-LI expression in immune cells. (D) The association between overall survival and PD-LI expression in immune cells. 
Table 3 Cox Regression Analysis on PD-LI Expression and Prognosis

\begin{tabular}{|c|c|c|c|c|c|c|}
\hline & \multicolumn{2}{|c|}{ Disease-Free Survival } & \multirow[t]{2}{*}{ p-value } & \multicolumn{2}{|c|}{ Overall Survival } & \multirow[t]{2}{*}{ p-value } \\
\hline & HR & $95 \% \mathrm{Cl}$ & & HR & $95 \% \mathrm{Cl}$ & \\
\hline $\begin{array}{l}\text { Univariate analysis } \\
\text { PD-LI expression in tumor cells } \leq 5 \% \\
\text { PD-LI expression in tumor cells }>5 \%\end{array}$ & $\begin{array}{l}1.00 \\
1.76\end{array}$ & $1.04,2.98$ & 0.035 & $\begin{array}{l}1.00 \\
1.76\end{array}$ & $1.00,3.09$ & 0.053 \\
\hline $\begin{array}{l}\text { Multivariate analysis }^{\mathrm{a}} \\
\text { PD-LI expression in tumor cells } \leq 5 \% \\
\text { PD-LI expression in tumor cells }>5 \%\end{array}$ & $\begin{array}{l}1.00 \\
1.52\end{array}$ & $0.88,2.60$ & 0.132 & $\begin{array}{l}1.00 \\
1.48\end{array}$ & $0.82,2.69$ & 0.196 \\
\hline $\begin{array}{l}\text { Univariate analysis }^{\mathrm{b}} \\
\text { PD-LI expression in tumor cells } \leq 5 \% \\
\text { PD-LI expression in tumor cells }>5 \%\end{array}$ & $\begin{array}{l}1.00 \\
2.69\end{array}$ & $1.36,5.31$ & $0.004^{d}$ & $\begin{array}{l}1.00 \\
3.91\end{array}$ & I.79, 8.55 & $0.001^{d}$ \\
\hline $\begin{array}{l}\text { Multivariate analysis }{ }^{\mathrm{a}, \mathrm{b}} \\
\text { PD-LI expression in tumor cells } \leq 5 \% \\
\text { PD-LI expression in tumor cells }>5 \%\end{array}$ & $\begin{array}{l}1.00 \\
2.51\end{array}$ & $1.25,5.06$ & $0.010^{\mathrm{d}}$ & $\begin{array}{l}1.00 \\
3.51\end{array}$ & I.57, 7.85 & $0.002^{d}$ \\
\hline $\begin{array}{l}\text { Univariate analysis }^{c} \\
\text { PD-LI expression in tumor cells } \leq 5 \% \\
\text { PD-LI expression in tumor cells }>5 \%\end{array}$ & $\begin{array}{l}1.00 \\
1.18\end{array}$ & $0.4 I, 3.42$ & 0.759 & $\begin{array}{l}1.00 \\
0.88\end{array}$ & $0.28,2.76$ & 0.820 \\
\hline $\begin{array}{l}\text { Multivariate analysis }{ }^{\mathrm{a}, \mathrm{c}} \\
\text { PD-LI expression in tumor cells } \leq 5 \% \\
\text { PD-LI expression in tumor cells }>5 \%\end{array}$ & $\begin{array}{l}1.00 \\
1.07\end{array}$ & $0.34,3.31$ & 0.911 & $\begin{array}{l}1.00 \\
0.63\end{array}$ & $0.18,2.26$ & 0.479 \\
\hline
\end{tabular}

Notes: ${ }^{\mathrm{a}}$ Further adjusting age, sex and blood vessel invasion; ${ }^{\mathrm{b}} \mathrm{PD}-\mathrm{LI}$ expression rate $\leq 30 \%$ in immune cells; ${ }^{\mathrm{C}} \mathrm{PD}-\mathrm{LI}$ expression rate $>30 \%$ in immune cells; ${ }^{\mathrm{d}} \mathrm{P}<0.05$.

interactive effect of PD-L1 expression between TC and IC on prognosis.

The median expression rate of PD-L1 was 5\% in TC and $30 \%$ in IC, which were lower than the reported value in previous literatures. Hatogai et al found $18.4 \%$ TC and 60.7\% IC expressing PD-L1 in tumor microenvironment among ESCC patients at the stage of $\mathrm{T} 2$ at least. ${ }^{14}$ Additionally, Chen et al recruited patients with neoadjuvant chemoradiotherapy and found that $45 \%$ of them had the PDL1 expression. ${ }^{8}$ Radiation was reported to elicit an adaptive immune response and the PD-L1 expression in tumor microenvironment could undermine the immunogenic effect of radiation. ${ }^{15}$ This study excluded the ESCC patients with neoadjuvant and immunotherapy, and the variation in patient selection might introduce the inconsistent expression rate.

Similarly, the PD-L1 expression in IC did not have an association with the lymph node metastasis, tumor stage, neural invasion or blood vessel invasion. ${ }^{10,16}$ The PD-L1 expression in TC and IC had no relevance with the clinical and pathological factors, but both were associated with a favorable survival. ${ }^{14}$ Xu's study found that PD-L1 could be a significant biomarker in poor prognosis and adverse clinicopathologic features (high TNM stage, poor nuclear grade and necrosis) of renal cell carcinoma. ${ }^{17}$ Elevated PD-
L1 also had a significant association with an enhanced mortality risk (combined RR 2.90, 95\% CI: 1.64, 5.13). ${ }^{17}$ Jiang also reported the significant effect of PD-L expression in TC on prognosis. ${ }^{16}$ However, in our study, the significant effect of PD-L1 expression in TC was only observed among patients with the PD-L1 expression rate in IC less than $30 \%$. The interactive effects of PD-L1 expression on TC and IC were seldom reported, but the combined assessment of PD-L1 expressed on TC and IC was recommended on the guidelines of check-point inhibitor immunotherapy. ${ }^{13}$

The PD-L1 expression in TC inhibited the immune function of T cells and induced the immune escape of cancer cells. ${ }^{18}$ The dendritic cells expressing PD-L1 were unable to activate the proliferation of $\mathrm{CD}^{+} \mathrm{T}$ cells, and the antibody against $\mathrm{PD}-$ L1 could restore the activation. ${ }^{19}$ Effector $\mathrm{CD} 8{ }^{+} \mathrm{T}$ cells primed in the presence of PD-L1 signaling decreased cytokine secretion and cytotoxicity activity, compared to the $\mathrm{CD} 8^{+} \mathrm{T}$ cells primed in the absence of PD-L1 ${ }^{20}$ PD-L1 expression of tumorassociated, myeloid-derived suppressor cells and macrophages exhibited immune suppression and related to the cancer progression. ${ }^{21}$ The expression and function of PD-L1 were reported to be impacted by regulators of the immune response, such as cytotoxic $\mathrm{T}$ lymphocyte-associated antigen 4 (CTLA4), T-cell immunoglobulin and mucin domain 3 (TIM-3), 

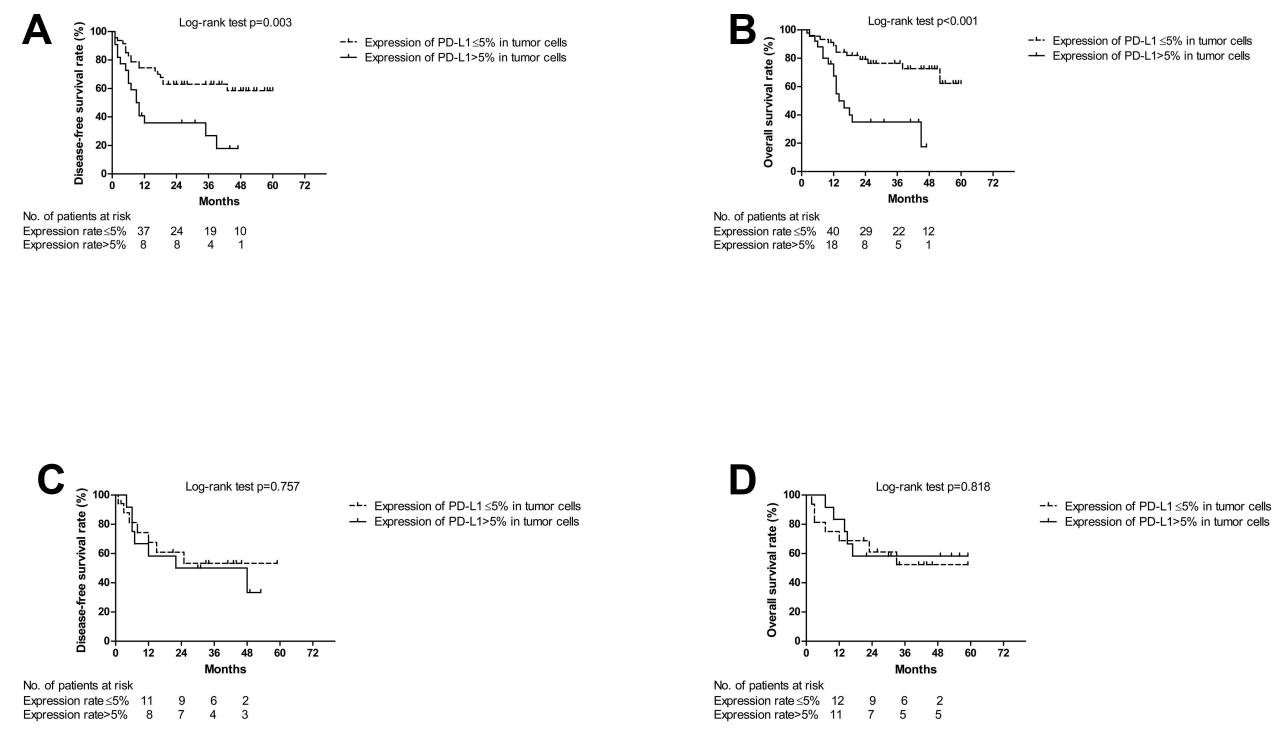

Figure 2 The association between the survival and PD-LI expression in tumor cells by the stratification of PD-LI in immune cells. (A) Disease-free survival among patients with PD-LI expression $\leq 30 \%$ in immune cells. (B) Overall survival among patients with PD-LI expression $\leq 30 \%$ in immune cells. (C) Disease-free survival among patients with PD-LI expression $>30 \%$ in immune cells. (D) Overall survival among patients with PD-LI expression $>30 \%$ in immune cells.

lymphocyte activation gene 3 (LAG-3) and CD38. ${ }^{22,23}$ The PD-1/PD-L1 signaling pathway blockade is affected by tumor immune microenvironments. PD-L1 expression on TC or tumor-infiltrating IC is closely related to clinicopathological features and survival of several tumors. ${ }^{24}$ PD-L1 had been reported to be correlated with the epithelial-mesenchymal transition (EMT) by down-regulation of E-cadherin and upregulation of N-cadherin. ${ }^{25}$ EMT influenced the tumor immunemicroenvironment and was a negative survival predictor. ${ }^{26}$

High PD-L1 expression rate in IC indicated a suppressive immune environment, and under the suppressive immune system PD-L1 expressed in TC played a limited role in immune inhibition. The PD-1/PD-L1 signaling pathway is identified as conveying an inhibitory signal to $\mathrm{T}$ cells and activating the immune escape of cancer cells. $^{27}$ PD-L1 is a cell surface glycoprotein expressed on $\mathrm{TC}$ and $\mathrm{IC}$, and the interaction with PD-1 on $\mathrm{T}$ cells impedes immune response. ${ }^{24}$ Therefore, it was necessary to use combining the expression of PD-L1 on TC with IC to predict the prognosis of ESCC. Our study demonstrated if the expression of PD-L1 on IC was low, the effector immune cells were less dysfunctional and the expression of PD-L1 on TC affected the immunity and had a significant effect on the prognosis of ESCC. On the contrary, the high expression of PD-L1 on IC represented a low response or depletion of cell immunity, and the expression of PD-L1 on TC was less likely to affect cell immunity and had no significance to the prognosis of ESCC. The limitations of this study include small sample size, the short duration of follow-up and the use of tissues fixed in paraffin wax.

\section{Conclusion}

Our study demonstrates that PD-L1 is a significant prognostic factor for operable patients of ESCC with a lower expression rate in IC. The integration of the PD-L1 expression on TC and IC could be used to predict the relapse and survival of patients with ESCC.

\section{Informed Consent}

This study was under a retrospective study, patients were inaccessible to be contacted and the informed consent was waivered. The data were anonymized or maintained with confidentiality.

\section{Ethical Approval}

All procedures performed in this study involving human participants were approved by the ethical committee of Beijing Shijitan Hospital, Capital Medical University, in accordance with the ethical standards of the 1964 Helsinki declaration and its later amendments.

\section{Funding}

This study was financially supported by the Digestive Medical Coordinated Development Center of Beijing Hospitals Authority (QKSXXT16) and Beijing Municipal Bureau of Health (QKS 2015-3-057). The supporting 
organizations had no role in study design, data collection, analysis, or interpretation.

\section{Disclosure}

The authors declare that they have no conflicts of interest.

\section{References}

1. Bray F, Ferlay J, Soerjomataram I, Siegel RL, Torre LA, Jemal A. Global cancer statistics 2018: GLOBOCAN estimates of incidence and mortality worldwide for 36 cancers in 185 countries. CA Cancer J Clin. 2018;68(6):394-424. doi:10.3322/caac.21492

2. Zeng $\mathrm{H}$, Zheng R, Zhang S, et al. Esophageal cancer statistics in China, 2011: estimates based on 177 cancer registries. Thorac Cancer. 2016;7(2):232-237. doi:10.1111/1759-7714.12322

3. Zeng H, Chen W, Zheng R, et al. Changing cancer survival in China during 2003-15: a pooled analysis of 17 population-based cancer registries. Lancet Global Health. 2018;6(5):e555-e567. doi:10.1016/ S2214-109X(18)30127-X

4. Ku GY. The current status of immunotherapies in esophagogastric Cancer. Hematol Oncol Clin North Am. 2019;33(2):323-338. doi:10.1016/j.hoc.2018.12.007

5. Fesnak AD, June CH, Levine BL. Engineered T cells: the promise and challenges of cancer immunotherapy. Nat Rev Cancer. 2016;16 (9):566-581. doi:10.1038/nrc.2016.97

6. Schutz F, Stefanovic S, Mayer L, von Au A, Domschke C, Sohn C. PD-1/PD-L1 pathway in breast cancer. Oncol Res Treat. 2017;40 (5):294-297. doi:10.1159/000464353

7. Dunn G, Bruce AT, Ikeda H, Old LJ, Schreiber RD. Cancer immunoediting: from immunosurveillance to tumor escape. Nat Immunol. 2002;3(11):991-998. doi:10.1038/ni1102-991

8. Chen K, Cheng G, Zhang F, et al. Prognostic significance of programmed death-1 and programmed death-ligand 1 expression in patients with esophageal squamous cell carcinoma. Oncotarget. 2016;7(21):30772-30780. doi:10.18632/oncotarget.8956

9. Guo W, Zhang F, Shao F, et al. PD-L1 expression on tumor cells associated with favorable prognosis in surgically resected esophageal squamous cell carcinoma. Hum Pathol. 2019;84:291-298. doi:10.1016/j.humpath.2018.09.014

10. Chen MF, Chen PT, Chen WC, Lu MS, Lin PY, Lee KD. The role of PD-L1 in the radiation response and prognosis for esophageal squamous cell carcinoma related to IL-6 and T-cell immunosuppression. Oncotarget. 2016;7(7):7913-7924. doi:10.18632/oncotarget.6861

11. Chen L, Xiong Y, Li J, et al. PD-L1 expression promotes epithelial to mesenchymal transition in human esophageal cancer. Cell Physiol Biochem. 2017;42(6):2267-2280. doi:10.1159/000480000

12. Wang Q, Feng F, Wang F, et al. PD-L1 expression on tumor cells was associated with unfavorable prognosis in esophageal squamous cell carcinoma. J Cancer. 2018;9(12):2224-2231. doi:10.7150/jca.24493

13. Ajani JA, D'Amico TA, Bentrem DJ, et al. Esophageal and esophagogastric junction cancers, version 2.2019, NCCN clinical practice guidelines in oncology. $J$ Natl Compr Canc Netw. 2019;17 (7):855-883. doi:10.6004/jncen.2019.0033
14. Hatogai K, Kitano S, Fujii S, et al. Comprehensive immunohistochemical analysis of tumor microenvironment immune status in esophageal squamous cell carcinoma. Oncotarget. 2016;7 (30):47252-47264. doi:10.18632/oncotarget.10055

15. Jeong H, Bok S, Hong BJ, Choi HS, Ahn GO. Radiation-induced immune responses: mechanisms and therapeutic perspectives. Blood Res. 2016;51(3):157-163. doi:10.5045/br.2016.51.3.157

16. Jiang Y, Lo AWI, Wong A, et al. Prognostic significance of tumor-infiltrating immune cells and PD-L1 expression in esophageal squamous cell carcinoma. Oncotarget. 2017;8(18):30175-30189. doi:10.18632/oncotarget.15621

17. Xu F, Xu L, Wang Q, An G, Feng G, Liu F. Clinicopathological and prognostic value of programmed death ligand-1 (PD-L1) in renal cell carcinoma: a meta-analysis. Int $J$ Clin Exp Med. 2015;8 (9):14595-14603.

18. Juneja VR, McGuire KA, Manguso RT, et al. PD-L1 on tumor cells is sufficient for immune evasion in immunogenic tumors and inhibits CD8 T cell cytotoxicity. $J$ Exp Med. 2017;214(4):895-904. doi:10.1084/jem.20160801

19. Pulko V, Liu X, Krco CJ, et al. TLR3-stimulated dendritic cells up-regulate B7-H1 expression and influence the magnitude of $\mathrm{CD} 8$ $\mathrm{T}$ cell responses to tumor vaccination. J Immunol. 2009;183 (6):3634-3641. doi:10.4049/jimmunol.0900974

20. Benedict CA, Loewendorf A, Garcia Z, Blazar BR, Janssen EM. Dendritic cell programming by cytomegalovirus stunts naive $\mathrm{T}$ cell responses via the PD-L1/PD-1 pathway. J Immunol. 2008;180 (7):4836-4847. doi:10.4049/jimmunol.180.7.4836

21. Gibbons Johnson RM, Dong H. Functional expression of programmed death-ligand 1 (B7-H1) by immune cells and tumor cells. Front Immunol. 2017;8:961. doi:10.3389/fimmu.2017.00961

22. Gros A, Robbins PF, Yao X, et al. PD-1 identifies the patient-specific $\mathrm{CD} 8(+)$ tumor-reactive repertoire infiltrating human tumors. J Clin Invest. 2014;124(5):2246-2259. doi:10.1172/JCI73639

23. Chen L, Diao L, Yang Y, et al. CD38-mediated immunosuppression as a mechanism of tumor cell escape from PD-1/PD-L1 blockade. Cancer Discov. 2018;8(9):1156-1175. doi:10.1158/2159-8290.CD17-1033

24. Pardoll DM. The blockade of immune checkpoints in cancer immunotherapy. Nat Rev Cancer. 2012;12(4):252-264. doi:10.1038/ nrc3239

25. Cao Y, Zhang L, Kamimura Y, et al. B7-H1 overexpression regulates epithelial-mesenchymal transition and accelerates carcinogenesis in skin. Cancer Res. 2011;71(4):1235-1243. doi:10.1158/0008-5472. CAN-10-2217

26. Manjunath Y, Upparahalli SV, Avella DM, et al. PD-L1 expression with epithelial mesenchymal transition of circulating tumor cells is associated with poor survival in curatively resected non-small cell lung cancer. Cancers (Basel). 2019;11(6):e806. doi:10.3390/ cancers 11060806

27. Bour-Jordan H, Esensten JH, Martinez-Llordella M, Penaranda C, Stumpf M, Bluestone JA. Intrinsic and extrinsic control of peripheral T-cell tolerance by costimulatory molecules of the CD28/B7 family. Immunol Rev. 2011;241(1):180-205. doi:10.1111/j.1600065X.2011.01011.x 


\section{Publish your work in this journal}

OncoTargets and Therapy is an international, peer-reviewed, open access journal focusing on the pathological basis of all cancers, potential targets for therapy and treatment protocols employed to improve the management of cancer patients. The journal also focuses on the impact of management programs and new therapeutic agents and protocols on patient perspectives such as quality of life, adherence and satisfaction. The manuscript management system is completely online and includes a very quick and fair peer-review system, which is all easy to use. Visit http://www.dovepress.com/ testimonials.php to read real quotes from published authors.

Submit your manuscript here: https://www.dovepress.com/oncotargets-and-therapy-journal 